\title{
Effect of Different Levels of Naphthalene Acetic Acid at Various Phenological Stages of Hybrid Sorghum to Enhance Fodder Productivity
}

\author{
Iqtidar Hussain*, Muzafar Ali, Imam Bakhsh and Muhammad Waqas Imam Malik
}

Department of Agronomy, Faculty of Agriculture, Gomal University, Dera Ismail Khan, Khyber Pakbtunkhwa, Pakistan.

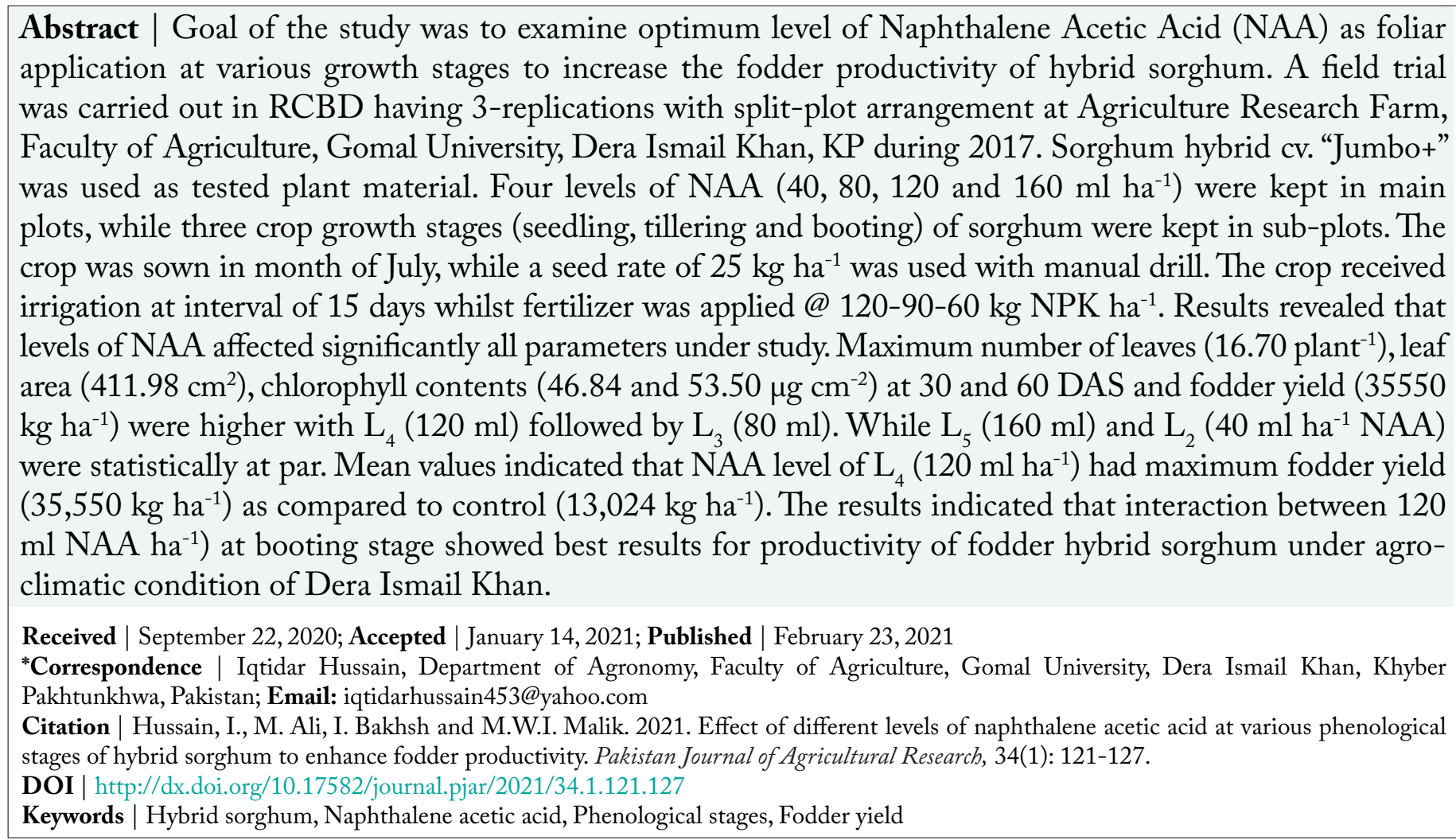

\section{Introduction}

Sorghum crop is grown on area of $39.33 \mathrm{~m}$ ha in the world with production of $59.34 \mathrm{~m}$ metric ton (USDA, 2018). It is cultivated in dryer zones of Asia, Australia and America. It is $5^{\text {th }}$ important cereal crop after wheat, rice, barley, and is source of food for more than 600 million people in different countries (Kumar et al., 2011). In Pakistan during year 2018, cultivated area of sorghum was 255 thousand hectares with the 154 thousand tons production (Anonymous, 2018). It is grown as a forage as well as sugar crop, biofuel crop and is mostly used as grain crop. In current situation, demand of grain and fodder sorghum is increasing day by day. In May-June and Oct-Nov, lack of fodder is quite common in Pakistan; it may be cultivated under irrigation and barani farming systems (Khan et al., 2013). Plant Growth Regulators (PGRs) for yield development, quality development and facilitation of harvesting together with genetic engineering represent supplementary techniques in agriculture for enhancing production of crop and usage of few 
resources. While, PGRs have been used in agriculture for crop protection as their adverse chemical effect has been comparatively less and limited to some specific culture (Djanaguiraman and Ramesh, 2013).

Applications of PGRs are useful not only to achieve the quality desired by the ethanol industry (Almodares et al., 2013) but the quality needed for other purposes as forage also. PGRs are compounds able to change the morphology and physiology of plants and can be applied at different times (Leite et al., 2011), depending on the grower purpose for crop. G3 (70 ppm NAA $\mathrm{ha}^{-1}$ ) revealed the greater chlorophyll content. A quadratic association was originating $\mathrm{b} / \mathrm{w}$ the chlorophyll and NAA level (Nagraj, 2009). Plant growth regulators are often used to control lodging by using chlormequat chloride (CCC), a gibberellin biosynthesis inhibitor (Rajala et al., 2002). ETH application also prohibited the lodging and was related with decrease in plant height, increase in stem wall width of $1^{\text {st }}, 2^{\text {nd }}$ and $3^{\text {rd }}$ internodes (Tripathi et al., 2003). Current study was showed to examine effects of exogenous application of various levels of NAA on morphological traits of hybrid sorghum at 3-critical crop growth stages and to find the impact of NAA on green fodder production.

\section{Materials and Methods}

\section{Site of experimentation}

An experiment was undertaken at ARI D.I. Khan during 2017. Five samples were collected from the field from 0 to $30 \mathrm{~cm}$ depth. All the samples were individually analyzed for physic-chemical properties. The observations depicted that the soil was calcareous in nature while the location received low rainfall i.e. 180-250 $\mathrm{mm}$ with high summer temperature (35-40 ${ }^{\circ} \mathrm{C}$ ) and a $\mathrm{pH}$ of more than 8.0. During the study year, total rainfall was recorded to be $215 \mathrm{~mm}$.

\section{Experimental procedure}

Research experiment on effect of different levels of NAA at various phenological stages of hybrid sorghum to enhance fodder productivity was conducted at Agriculture Research Farm, Faculty of Agriculture, GU, Dera Ismail Khan, during 2017. This research trial was laid out in RCBD having three replicates with split-plot arrangement. Net plot size was $4 \times 3 \mathrm{~m}$ having $60 \mathrm{~cm}$ row to row managed at ridge sowing in each plot. Experiment included two factors i.e. five levels of NAA and three crop growth stages of sorghum. The field was prepared by applying one disc ploughing, one rotavator tillage and two cultivator ploughings with land leveling. Seed rate was $25 \mathrm{~kg} \mathrm{ha}^{-1}$ for fodder. Sowing was done with hand drill. Sorghum hybrid "Jumbo+" was sown during the $3^{\text {rd }}$ week of July. The fertilizer dose was applied 120-90-60 kg NPK ha-1. The full dose of phosphorus, potassium and half level of nitrogen dose were used at sowing time, whereas remaining half level of $\mathrm{N}$ was used at tillering. Planofix (NAA) was applied by hand pump sprayer with $4.5 \%$ concentration as sodium salt in five levels at seedling, booting and tillering stage. NAA is a biodegradable and environment friendly chemical. Each concentration was made by dissolving each concentration $(0,40,80,120$ and 160) dissolved in one litter of distilled water to make the required dose. These concentrations are made by reviewing past literature and finding. The experimental procedure and treatments details are given below;

Table: Table showing weather conditions at experimental site (2017).

\begin{tabular}{lccll} 
Month & \multicolumn{3}{c}{ Temperature ${ }^{\circ} \mathbf{C}$} & R.F. (mm) \\
& Max & Min. & Avg. & \\
May & 37.8 & 22.5 & 30.15 & 16.0 \\
June & 40.7 & 26.3 & 33.5 & 7.0 \\
July & 44.9 & 26.3 & 35.6 & 112.0 \\
Aug. & 40.0 & 21.1 & 30.55 & 40.0 \\
Sept. & 39.0 & 17.0 & 28.0 & 42.0 \\
Oct. & 35.5 & 16.7 & 26.1 & -- \\
Nov & 26.7 & 11.6 & 19.15 & 4.0
\end{tabular}

Total rainfall $(\mathrm{mm}) 219.0$

$\begin{array}{ll}\begin{array}{l}\text { Main-plot } \\ \text { (NAA Levels) }\end{array} & \text { Sub-plot (Crop growth stages) } \\ \mathrm{L}_{1}=0 \mathrm{ml} \mathrm{ha}^{-1} & \mathrm{~S}_{1}=\text { Seedling stage (25 days after sowing) } \\ \mathrm{L}_{2}=40 \mathrm{ml} \mathrm{ha}^{-1} & \mathrm{~S}_{2}=\text { Tillering stage (35 days after sowing) } \\ \mathrm{L}_{3}=80 \mathrm{ml} \mathrm{ha}^{-1} & \mathrm{~S}_{3}=\text { Booting stage (45 days after sowing) } \\ \mathrm{L}_{4}=120 \mathrm{ml} \mathrm{ha}^{-1} & \\ \mathrm{~L}_{5}=160 \mathrm{ml} \mathrm{ha}^{-1} & \end{array}$

\section{Parameters recorded}

The data on following parameters was recorded.

\section{Number of leaves plant ${ }^{-1}$}

Green leaves per plant were counted at maturity in 5 plants randomly tagged in every sub-plot and their average was calculated. 
Leaf area plant ${ }^{-1}$

Leaf area was measured by calculating width and length of 5 leaves per plant randomly selected in every treatment by help of scale and averaged. The leaf area was measured in every treatment using formula:

Leaf area $=$ Length of leaf $\times$ Width of leaf $\times$ Correction factor (0.75) $\times$ Number of leaves per plant

Correction factor for leaf area is called as potsaaium coefficient and values for sorghum is 0.75 (Musa et al., 2016).

\section{Chlorophyll contents $\left(\mu \mathrm{g} \mathrm{cm}^{-2}\right.$ )}

Chlorophyll concentration was measured before heading. Five randomly plants were tagged from every sub plots. Photo SPAD meter was used for measurement of chlorophyll contents.

\section{Fodder yield $\left(\mathrm{kg} \mathrm{ha}^{-1}\right)$}

Weight of total harvested material $\left(1 \mathrm{~m}^{2}\right)$ in every plot was recorded and then converted to kilogram per hectare with the help of following formula:

$$
\text { Fodder yield }\left(\mathrm{kg} \mathrm{ha}^{-1}\right)=\operatorname{Weight}\left(1 \mathrm{~m}^{2}\right) \times 10000
$$

\section{Benefit cost ratio ( $B C R$ )}

BCR was calculated for every sub plot using the method proposed by Rahman et al. (2009) as under:

$$
B C R=\text { Benefits } / \text { Expenditure }
$$

\section{Statistical analysis}

Data was recorded and examined by using ANOVA technique (Steel et al. 1997) with subsequent evaluation of distinct treatment means done (Black, 2011). ANOVA was accomplished using "Statistix 8.1" software.

\section{Results and Discussion}

\section{Number of leaves plant ${ }^{-1}$}

Data analysis revealed that effect of different levels of NAA at various growth stages of sorghum and their interactions showed significant effects on No. of leaves (Table 1). Mean values of No. of leaves indicated that $\mathrm{L}_{5}\left(160 \mathrm{ml} \mathrm{NAA} \mathrm{ha} \mathrm{N}^{-1}\right)$ had the highest number of leaves $\left(16.70\right.$ plant $\left.^{-1}\right)$ which are statistically at par with $\mathrm{L}_{4}\left(120 \mathrm{ml} \mathrm{ha}^{-1}\right) \mathrm{NAA}$ followed by $\mathrm{L}_{1}(0$ $\left.\mathrm{ml} \mathrm{ha}{ }^{-1}\right), \mathrm{L}_{2}\left(40 \mathrm{ml} \mathrm{ha}^{-1}\right), \mathrm{L}_{3}\left(80 \mathrm{ml} \mathrm{ha}^{-1}\right)$, respectively. Numbers of leaves were recorded as the lowest
(13.50 plant $^{-1}$ ) in $\mathrm{L}_{0}$ (control plot). Mean values of growth stages revealed that NAA application at booting stage produced higher number of leaves (16.41 plant $^{-1}$ ) followed by $\mathrm{S}_{2}$ (tillering stag), while $\mathrm{S}_{1}$ (seedling stage) produced the lowest number of leaves (14.36 plant $\left.^{-1}\right)$. Interaction effect of NAA levels and crop growth stages revealed that $\mathrm{S}_{3} \mathrm{~L}_{4}$ had highest No. of leaves (18.20 plant $\left.^{-1}\right)$, followed by $\mathrm{L}_{4}\left(\mathrm{~L}_{5} \mathrm{~S}_{3}\right) \mathrm{x}$ $\left(\mathrm{L}_{5} \mathrm{~S}_{2}\right)$, and the lowest No. of leaves (12.53 plant $^{-1}$ ) were recorded in $\mathrm{L}_{0} \mathrm{~S}_{1}$ (control). Related results were found by Durrani et al. (2010) who reported that plant height at 40 days after sowing, number of leaves were recorded maximum. Durrani et al. (2010) and Almodares et al. (2011), described that yield and its components were increased with application of naphthalene acetic acid. Similar result was reported that decline in leaf production at 800 ppm could be attributed to the fact that at lower concentrations most plant growth regulators stimulated plant growth and at higher concentrations, inhibited plant growth (Basuchaudhuri, 2016).

\section{Leaf area plant ${ }^{-1}$}

Data shown in Table 2 regarding leaf area $\left(\mathrm{cm}^{2}\right)$ per plant was affected significantly by various levels of naphthalene acetic acid and crop growth stages, however, their interactions were not significant. Mean values for the levels of naphthalene acetic acid revealed that $\mathrm{L}_{5}\left(160 \mathrm{ml} \mathrm{NAA} \mathrm{ha}{ }^{-1}\right)$ had higher leaf area $\left(411.98 \mathrm{~cm}^{2}\right)$ compared with other levels. The highest leaf area $\left(375.27 \mathrm{~cm}^{2}\right)$ was recorded in $\mathrm{S}_{3}$ (booting stage). When levels of naphthalene acetic acid increased, leaf area was also increased. Govindan et al. (2000) also conveyed similar findings and reported that plants sprayed with NAA (40 ppm) showed significantly increased leaf area $\left(\mathrm{cm}^{2}\right)$. Moreover, they stated that $150+60 \mathrm{ppm}(\mathrm{IAA}+\mathrm{NAA})$ gave the highest values of leaf area $\left(\mathrm{cm}^{2}\right)$. Similar results were found by Khan and Chaudhry (2006). Mona et al. (2013) concluded that various levels of naphthalene acetic acid significantly affected leaf area $\left(\mathrm{cm}^{2}\right)$, while different growth stages also produced variation in leaf area. Interactive effect of NAA levels and crop growth stages revealed that $\mathrm{L}_{5} \mathrm{~S}_{3}$ produced maximum leaf area $\left(419.07 \mathrm{~cm}^{2}\right)$ which is statistically similar to other treatments (Non-significant) and the lowest leaf area $\left(402.87 \mathrm{~cm}^{2}\right)$ was recorded in $\mathrm{L}_{0} \mathrm{~S}_{1}$. It may be due to the fact that leaf area is inherited character of specie and less influenced by exogenous application of materials. 
Table 1: Number of leaves plant ${ }^{-1}$ of hybrid sorghum as affected by NAA levels at different growth stages.

\section{Growth stages}

$\mathrm{S}_{1}=$ Seedling stage

$\mathrm{S}_{2}=$ Tillering stage

$\mathrm{S}_{3}=$ Booting stage

Mean
NAA (levels)

$\mathbf{L}_{3}=\mathbf{8 0}$
$14.37 \mathrm{~g}$
$15.23 \mathrm{f}$
$16.43 \mathrm{~cd}$
$15.34 \mathrm{~b}$

$\mathrm{L}_{\mathbf{4}}=\mathbf{1 2 0}$

$15.27 \mathrm{f}$

16.00 de

$18.20 \mathrm{a}$

$16.49 \mathrm{a}$
Mean

$$
\mathbf{L}_{5}=\mathbf{1 6 0}
$$

$16.17 \mathrm{ce} \quad 14.36 \mathrm{c}$

$16.73 \mathrm{bc} \quad 15.14 \mathrm{~b}$

$17.20 \mathrm{~b} \quad 16.41 \mathrm{a}$

$16.70 \mathrm{a}$

$L S D_{0.05}$ values; $N A A$ levels $=0.44 ;$ Growth stages $=0.26 ;(L \times S)$ interaction $=0.58 ;$ Means having similar letter $(s)$ in each category are not significantly different at $P \geq 0.05$.

Table 2: Leaf area $\left(\mathrm{cm}^{2}\right)$ of bybrid sorghum as affected by NAA levels at different growth stages.

\section{Growth stages}

\section{$\mathrm{S}_{1}=$ Seedling stage \\ $\mathrm{S}_{2}=$ Tillering stage \\ $\mathrm{S}_{3}=$ Booting stage}

Mean

$$
\mathbf{L}_{1}=\mathbf{0}
$$

NS 314.47

320.83

323.00

319.43 c
NAA (levels)

$\begin{array}{ll}\mathbf{L}_{2}=\mathbf{4 0} & \mathbf{L}_{\mathbf{3}}=\mathbf{8 0} \\ 330.23 & 360.87 \\ 341.67 & 369.23 \\ 357.47 & 379.27 \\ 343.12 \mathrm{c} & 369.79 \mathrm{~b}\end{array}$

$$
\mathrm{L}_{\mathbf{4}}=120
$$

390.17

396.33

397.53

394.68 a

\section{Mean}

$$
L_{5}=160
$$

402.87

414.00

419.07

411.98 a
359.72 c

$368.41 \mathrm{~b}$

375.27 a

$L S D_{0.05}$ values; $N A A$ levels= 24.01; Growth stages=4.23; Means having similar letter (s) in each category are not significantly different at $P \geq 0.05$.

Table 3: Chlorophyll contents ( $\mu \mathrm{g} \mathrm{cm}^{-2}$ ) at 30 of bybrid sorghum as affected by $N A A$ levels at different growth stages.

\section{Growth stages}

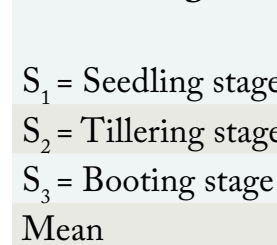

$\mathrm{S}_{1}=$ Seedling stage

$$
\mathbf{L}_{1}=\mathbf{0}
$$$$
40.57 \mathrm{k}
$$$$
42.37 \mathrm{j}
$$$$
42.80 \mathrm{ij}
$$

$41.91 \mathrm{~d}$

\section{NAA (levels)}

$\begin{array}{ll}\mathbf{L}_{\mathbf{3}}=\mathbf{8 0} & \mathbf{L}_{\mathbf{4}}=\mathbf{1 2 0} \\ 44.37 \mathrm{fg} & 45.37 \mathrm{de} \\ 44.60 \mathrm{ef} & 45.70 \mathrm{~cd} \\ 44.70 \mathrm{ef} & 47.90 \mathrm{a} \\ 44.56 \mathrm{~b} & 46.32 \mathrm{a}\end{array}$

Mean

\section{$\mathrm{L}_{5}=\mathbf{1 6 0}$}

$46.27 \mathrm{c}$

$46.87 \mathrm{~b}$

$47.40 \mathrm{ab}$

$46.84 \mathrm{a}$

$L S D_{0.05}$ values; $N A A$ levels $=0.62 ;$ Growth stages $=0.26 ;$ Interaction $=0.58 ;$ Means having similar letter (s) in each category are not significantly different at $P \geq 0.05$.

Table 4: Chlorophyll contents at $60\left(\mu \mathrm{g} \mathrm{cm}^{-2}\right)$ days of hybrid sorghum as affected by NAA levels at different growth stages.

\section{Growth stages}

$\mathrm{S}_{1}=$ Seedling stage

$\mathrm{S}_{2}=$ Tillering stage

$\mathrm{S}_{3}=$ Booting stage

Mean

\begin{tabular}{lll} 
& & \multicolumn{1}{c}{ NAA (levels) } \\
$\mathbf{L}_{\mathbf{1}}=\mathbf{0}$ & $\mathbf{L}_{\mathbf{2}}=\mathbf{4 0}$ & $\mathbf{L}_{\mathbf{3}}=\mathbf{8 0}$ \\
49.80 & 50.57 & 51.43 \\
50.03 & 50.93 & 51.50 \\
50.43 & 51.37 & 51.90 \\
$50.09 \mathrm{c}$ & $50.96 \mathrm{~b}$ & $51.61 \mathrm{~b}$
\end{tabular}

$\begin{array}{lll} & & \text { Mean } \\ \mathbf{L}_{\mathbf{4}}=\mathbf{1 2 0} & \mathbf{L}_{5}=\mathbf{1 6 0} & \\ 52.17 & 53.07 & 51.41 \mathrm{c} \\ 52.63 & 53.37 & 51.69 \mathrm{~b} \\ 54.57 & 54.07 & 52.47 \mathrm{a} \\ 53.12 \mathrm{a} & 53.50 \mathrm{a} & \end{array}$

$L S D_{0.05}$ value; $N A A$ levels $=0.68 ;$ Growth stages $=0.20$; Interaction $=0.44 ;$ Means having similar letter (s) in each category are not significantly different at $P \geq 0.05$.

Table 5: Fodder yield $\left(\mathrm{kg} \mathrm{ha}^{-1}\right)$ of hybrid sorghum as affected by NAA levels at different growth stages.

\section{Growth stages}

$\begin{array}{ll} & \mathbf{L}_{\mathbf{1}}=\mathbf{0} \\ \mathrm{S}_{1}=\text { Seedling stage } & 14390 \mathrm{~g} \\ \mathrm{~S}_{2}=\text { Tillering stage } & 14546 \mathrm{~g} \\ \mathrm{~S}_{3}=\text { Booting stage } & 14460 \mathrm{~g} \\ \text { Mean } & 14465 \mathrm{~d}\end{array}$

NAA (levels)

$\begin{array}{ll}\mathbf{L}_{2}=\mathbf{4 0} & \mathbf{L}_{\mathbf{3}}=\mathbf{8 0} \\ 14621 \mathrm{~g} & 20000 \mathrm{f} \\ 18033 \mathrm{f} & 25233 \mathrm{de} \\ 23765 \mathrm{e} & 32867 \mathrm{c} \\ 18806 \mathrm{c} & 26033 \mathrm{~b}\end{array}$

$\mathbf{L}_{\mathbf{4}}=\mathbf{1 2 0}$
$30033 \mathrm{c}$
$36267 \mathrm{~b}$
$40350 \mathrm{a}$
$35550 \mathrm{a}$

Mean

$\mathbf{L}_{5}=\mathbf{1 6 0}$
$26967 \mathrm{~d}$
$35817 \mathrm{~b}$
$39733 \mathrm{a}$
$34172 \mathrm{a}$

$43.98 \mathrm{c}$ $44.63 \mathrm{~b}$ $45.30 \mathrm{a}$

LSD values; NAA levels= 1638; Growth stages = 1270; $(L \times S)$ interaction= 2839; Means having similar letter $(s)$ in each category are not significantly different at $P \geq 0.05$. 
Chlorophyll contents at 30 days $\left(\mu \mathrm{g} \mathrm{cm}^{-2}\right)$

Data analysis (Table 3) showed that naphthalene acetic acid at different crop growth stages and their interactions had significant effects on chlorophyll contents. Mean values indicated that NAA level $\mathrm{L}_{5}\left(160 \mathrm{ml} \mathrm{ha}^{-1}\right)$ had maximum chlorophyll (46.84) which was statistically similar to $\mathrm{L}_{4}(120 \mathrm{ml}$ ha $\left.{ }^{1}\right)$ followed by $\mathrm{L}_{3}\left(80 \mathrm{ml} \mathrm{ha}^{-1}\right)$ and $\mathrm{L}_{2}\left(40 \mathrm{ml} \mathrm{ha}^{-1}\right)$. Minimum chlorophyll content (41.91) was recorded in $\mathrm{L}_{1}$ (control). Mean values of crop growth stages revealed that $\mathrm{S}_{3}$ (booting stage) produced maximum chlorophyll contents (45.30) followed by $\mathrm{S}_{2}$ (tillering stage), while $\mathrm{S}_{1}$ (seedling stage) produced minimum chlorophyll contents (43.98). Interaction of NAA levels and plant growth stages revealed that $\mathrm{L}_{4} \mathrm{~S}_{3}$ produced the highest chlorophyll contents (47.90) followed by $\mathrm{L}_{4} \mathrm{~S}_{2}$ and $\mathrm{L}_{4} \mathrm{~S}_{1}$, respectively. Minimum chlorophyll content (40.57) was recorded in $\mathrm{L}_{1}$ $x \mathrm{~S}_{1}$. It is further concluded that a higher levels of naphthalene acetic acid increase crop growth rate. Sivakumar et al. (2002) conveyed similar findings and reported that application of 20 ppm NAA increased chlorophyll in leaf of pearl millet. Begum et al. (2018) showed similar results and reported that different naphthalene acetic acid levels had significant effects on chlorophyll contents.

\section{Chlorophyll contents at 60 days $\left(\mu \mathrm{g} \mathrm{cm}^{-2}\right)$}

Data analysis depicted that various levels of naphthalene acetic acid at crop growth stages and their interactions had significant effects on chlorophyll contents (Table 4). Mean values indicated that NAA level at $\mathrm{L}_{5}\left(160 \mathrm{ml} \mathrm{ha}^{-1}\right)$ had maximum chlorophyll contents (53.50), which was statistically similar to $\mathrm{S}_{4}$ $\left(120 \mathrm{ml} \mathrm{ha}^{-1}\right)$ followed by $\mathrm{L}_{3}\left(80 \mathrm{ml} \mathrm{ha}^{-1}\right)$ and $\mathrm{L}_{2}(40$ $\mathrm{ml} \mathrm{ha}^{-1}$ ). Minimum chlorophyll content (50.09) was recorded in $\mathrm{L}_{1}$ (control). Mean values of crop growth stages of sorghum revealed that $\mathrm{S}_{3}$ (booting stage) produced maximum chlorophyll contents (52.47) followed by $\mathrm{S}_{2}$ (tillering stage), while $\mathrm{S}_{1}$ (seedling stage) produced minimum chlorophyll contents (51.41). Interaction of NAA levels and plant growth stages revealed that $\mathrm{L}_{4} \mathrm{~S}_{3}$ produced the highest chlorophyll contents (54.57), followed by $\mathrm{L}_{4} \mathrm{~S}_{4}$ and $\mathrm{L}_{4} \mathrm{~S}_{1}$, respectively. Minimum chlorophyll (49.80) was recorded in $\mathrm{L}_{1} \times \mathrm{S}_{1}$. Similar results were found by Viana et al. (2016). Begum et al. (2018) took similar conclusions and reported that different naphthalene acetic acid levels had significant effects on chlorophyll contents.

Table 6: BCR of hybrid sorghum as affected by NAA levels at different growth stages.

\begin{tabular}{|c|c|c|c|c|c|c|}
\hline $\begin{array}{l}\text { Plant growth regulator } \\
\text { level + growth stages }\end{array}$ & $\begin{array}{l}\text { Fodder yield } \\
\left(\mathrm{kg} \mathrm{ha}^{-1}\right)\end{array}$ & $\begin{array}{l}\text { Total variable cost } \\
\left(\mathrm{Rs} \mathrm{ha}^{-1}\right)\end{array}$ & $\begin{array}{l}\text { Gross income } \\
\left(\text { Rs. } \mathbf{h a}^{-1}\right)\end{array}$ & $\begin{array}{l}\text { Total cost (Rs. } \\
\text { ha }^{-1} \text { ) }\end{array}$ & $\begin{array}{l}\text { Net income (Rs. } \\
\left.\text { ha' }^{-1}\right)\end{array}$ & BCR \\
\hline $\mathrm{L}_{1}\left(0 \mathrm{ml} \mathrm{ha}^{-1}\right)$ & 14465 & 0 & 36162 & 35910 & 252 & 0.007 \\
\hline $\mathrm{L}_{2}\left(40 \mathrm{ml} \mathrm{ha} \mathrm{h}^{-1}\right)$ & 18806 & 33 & 47015 & 35943 & 11072 & 0.31 \\
\hline $\mathrm{L}_{3}\left(80 \mathrm{ml} \mathrm{ha}^{-1}\right)$ & 26033 & 66 & 65082 & 35976 & 29106 & 0.80 \\
\hline $\mathrm{L}_{4}\left(120 \mathrm{ml} \mathrm{ha}^{-1}\right)$ & 35550 & 99 & 88875 & 36009 & 52866 & 1.5 \\
\hline $\mathrm{L}_{5}\left(160 \mathrm{ml} \mathrm{ha}^{-1}\right)$ & 34172 & 132 & 85430 & 36042 & 49388 & 1.37 \\
\hline $\mathrm{S}_{1}$ (Seedling) & 21202 & 0 & 53005 & 35910 & 17095 & 0.47 \\
\hline $\mathrm{S}_{2}$ (Tillering) & 25979 & 0 & 64947 & 35910 & 29037 & 0.80 \\
\hline $\mathrm{S}_{3}$ (Booting) & 30235 & 0 & 75587 & 35910 & 39677 & 1.10 \\
\hline $\mathrm{L}_{1} \times \mathrm{S}_{1}$ & 14390 & 0 & 35975 & 35910 & 65 & 0.002 \\
\hline $\mathrm{L}_{1} \times \mathrm{S}_{2}$ & 14546 & 0 & 36365 & 35910 & 455 & 0.013 \\
\hline $\mathrm{L}_{1} \times \mathrm{S}_{3}$ & 14460 & 0 & 36150 & 35910 & 240 & 0.007 \\
\hline $\mathrm{L}_{2} \times \mathrm{S}_{1}^{3}$ & 14621 & 33 & 36552 & 35943 & 609 & 0.02 \\
\hline $\mathrm{L}_{2} \times \mathrm{S}_{2}$ & 18033 & 33 & 45082 & 35943 & 9140 & 0.25 \\
\hline $\mathrm{L}_{2} \times \mathrm{S}_{3}$ & 23765 & 33 & 59412 & 35943 & 23469 & 0.65 \\
\hline $\mathrm{L}_{3} \times \mathrm{S}_{1}$ & 20000 & 66 & 50000 & 35976 & 14024 & 0.39 \\
\hline $\mathrm{L}_{3} \times \mathrm{S}_{2}$ & 25233 & 66 & 63082 & 35976 & 27106 & 0.75 \\
\hline $\mathrm{L}_{3} \times \mathrm{S}_{3}$ & 32867 & 66 & 82167 & 35976 & 46191 & 1.28 \\
\hline $\mathrm{L}_{4} \times \mathrm{S}_{1}$ & 30033 & 99 & 75082 & 36009 & 39073 & 1.08 \\
\hline $\mathrm{L}_{4}^{4} \times \mathrm{S}_{2}$ & 36267 & 99 & 90667 & 36009 & 54659 & 1.51 \\
\hline $\mathrm{L}_{4} \times \mathrm{S}_{3}$ & 40350 & 99 & 100875 & 36009 & 64866 & 1.80 \\
\hline $\mathrm{L}_{5} \times \mathrm{S}_{1}$ & 26967 & 132 & 67417 & 36042 & 31375 & 0.87 \\
\hline $\mathrm{L}_{5} \times \mathrm{S}_{2}$ & 35817 & 132 & 89542 & 36042 & 53500 & 1.48 \\
\hline $\mathrm{L}_{5} \times \mathrm{S}_{3}$ & 39733 & 132 & 99332 & 36042 & 63290 & 1.75 \\
\hline
\end{tabular}


Fodder yield (kg ha $\left.\mathrm{ha}^{-1}\right)$

Data analysis (Table 5) indicated that effect of naphthalene acetic acid at different crop growth stages and their interactions had significant effects on fodder yield $\left(\mathrm{kg} \mathrm{ha}^{-1}\right)$. Mean values indicated that NAA level of $\mathrm{L}_{4}\left(120 \mathrm{ml} \mathrm{ha}^{-1}\right)$ had maximum fodder yield $\left(35,550 \mathrm{~kg} \mathrm{ha}^{-1}\right)$ which was statistically same as $\mathrm{L}_{5}\left(160 \mathrm{ml} \mathrm{ha}^{-1}\right)$ followed by $\mathrm{L}_{3}\left(80 \mathrm{ml} \mathrm{ha}^{-1}\right)$ and $\mathrm{L}_{2}\left(40 \mathrm{ml} \mathrm{ha}^{-1}\right)$, respectively. Minimum fodder yield $\left(13,024 \mathrm{~kg} \mathrm{ha}^{-1}\right)$ was recorded in $\mathrm{L}_{1}$ (control). Mean values of crop growth stages of sorghum revealed that $\mathrm{S}_{3}$ (booting stage) produced maximum fodder yield $\left(29,931 \mathrm{~kg} \mathrm{ha}^{-1}\right)$ followed by $\mathrm{S}_{2}$ (tillering stage), while $\mathrm{S}_{1}$ (seedling stage) produced minimum fodder yield $\left(20,897 \mathrm{~kg} \mathrm{ha}^{-1}\right)$. Interaction of NAA levels and plant growth stages revealed that $\mathrm{L}_{4} \mathrm{~S}_{3}$ produced the highest fodder yield $\left(40,350 \mathrm{~kg} \mathrm{ha}^{-1}\right)$ followed by $\mathrm{L}_{4} \mathrm{~S}_{2}$ and $\mathrm{L}_{4} \mathrm{~S}_{1}$, respectively. Minimum fodder yield $(12,867$ $\mathrm{kg} \mathrm{ha} \mathrm{h}^{-1}$ ) was recorded in $\mathrm{L}_{1} \mathrm{~S}_{1}$. The above treatments provided the balanced supply of all essential nutrients through growth regulator which synchronized with crop needs and uptake and thus, resulted in significantly higher fodder yield as compared to other treatments. The yield advantage might be due to the fact that the application of growth regulator has increased the sufficient quantity of essential nutrient which finally resulted in increased components and fodder yield (Gemici, 2003). The results are in line by Ullah et al. (2007). The results are also in line with Almodares et al. (2011) and Basuchaudhuri (2016) who reported that with increased level of NAA also directly contributed in the vegetative parts i.e. leaf area, size etc. enhancement which ultimately benefit the fodder yield.

\section{Benefit cost ratio (BCR)}

Data presented in Table 6 showed economic analysis of fodder hybrid of sorghum as affected by various levels of NAA and its growth stages. Cost of production and other economic details are given in Table 6. It is clear that $\mathrm{L}_{4} \mathrm{~S}_{3}$ had the maximum net income (Rs. 64,866 $\mathrm{ha}^{-1}$ ) with BCR 1.8, while minimum $\mathrm{L}_{1} \mathrm{~S}_{1}$ was noted (Rs.35,910) net profit with BCR 0.002. The second highest net income was calculated (Rs. 63,290) with BCR 1.75 in $\mathrm{L}_{5} \mathrm{~S}_{3}$.

\section{Conclusions and Recommendations}

Foliar application of naphthalene acetic acid $(120 \mathrm{ml}$ $\mathrm{ha}^{-1}$ ) produced more leaves and the highest fodder yield $\left(35,550 \mathrm{~kg} \mathrm{ha}^{-1}\right)$ at booting stage, while all other stages of sorghum had lower fodder yield. Therefore, it is concluded that booting stage is suitable for high fodder sorghum yield with $120 \mathrm{ml} \mathrm{NAA} \mathrm{ha}{ }^{-1}$ in Dera Ismail Khan.

\section{Novelty Statement}

Pakistan lying in that geographic area which is pound to climate change scenario and this climate change causes reduction in vegetative and economical yield of our summer crops. Considering the importance of naphthalene acetic acid (PGR) in reclaiming the climate change in physiology of sorghum the present research is designed accordingly.

\section{Author's Contribution}

Iqtidar Hussain: Principal investigator, technical help, overall management of the article.

Muzafar Ali: Co-principal investigator, data collection.

Imam Bakhsh: Farm manager, technical input.

Muhammad Waqas Imam Malik: Co-principal investigator, data collection, did SPSS analysis.

\section{Conflict of interest}

The authors have declared no conflict of interest.

\section{References}

Almodares, A., M. Usofzadeh and M. Daneshvar. 2013. Effect of nitrogen and ethephon on growth parameters, carbohydrate contents and bioethanol production from sweet sorghum. Int. J. Sugar Crops Related Ind., 15: 300-304. https://doi.org/10.1007/s12355-013-0246-5

Almodares, A.T. and M. Eraghizadeh. 2011. The effect of ethephon on biomass and carbohydrate content in two sweet sorghum cultivars. Int. J. Plant Prod., 5(3): 221-225.

Anonymous, 2018. Pakistan Economic Survey Finance Division GOP, Islamabad, Pakistan. pp. 19.

Basuchaudhuri, P., 2016. Influences of plant growth regulators on yield of soybean. Indian J. Plant Sci., 5(4): 25-38.

Begum,F., F.Hossain,M.M.Islam and R.I.Mondal. 2018. Effect of naphthalene acetic acid (NAA) on oil content and quality of the mustard plant (Brassica campestries L.). Pertanika. J. Trop. Agric. Sci., 41(1): 191-208. 
Black, K., 2011. Business statistics: For contemporary decision making. $7^{\text {th }}$ Ed. John Wiley and Sons. pp. 424.

Djanaguiraman, M. and D. Ramesh. 2013. Increasing millable cane yield of sweet sorghum through altered nitrogen, population level and plant growth regulators (NAA) spray. J. Crop Prod., 02: 08-18.

Durrani, F., M. Subhan, S. Mehmood, S. Abbas and F. Chaudhary. 2010. Enhancement of growth and yield components through foliar application of naphthalene acetic acid (NAA) and bezylaminopurine (BAP) in spinach. Sarhad J. Agric., 26(1): 31-36.

Gemici, M., 2003. Effect of cytozyme crop plus on Triticum durum (wheat). Dogaturk Botanik Dergisi, 17(3): 133-139.

Govindan, K., V.Thirumurugan and S. Arulchelvan. 2000. Response of soybean to growth regulators. Res. Crops, 1(3): 323-325.

Khan, A.H., M.S. Chohan, K.A. Husnain, Majid, R.A. Kainth, Nitasha and K. Majid. 2013. A new purpose sorghum bicolor cultivar for agroclimatic condition of Pakistan. J. Agric. Res., 51(1): 19-31.

Khan, A.S. and N.Y. Chaudhry. 2006. GA3 improves flower yield in some cucurbits treated with lead and mercury. Afr. J. Biotech., 5: 149153.

Kumar, A., B.V.S. Reddy, B. Ramaiah and R. Sharma. 2011. Heterosis in white grained grain mold resistant sorghum hybrids. e J. SAT Agric. Res., 9: 1-6.

Leite,G.H.P.,C.A.C.Cruscio and M.A.Silva.2011. Desenvolvimento e produtividade da canadeaçúcar após aplicação de reguladores vegetais em meio de safra semina. Ciências Agrárias, 32: 129-138. https://doi.org/10.5433/16790359.2011v32n1p129

Mona, E.E., A.K. Maymona and S.A. Ibrahim. 2013. Response of barley plants to foliar application of growth regulators mixture of indole acetic acid, naphthalene acetic acid and zinc. Afr. J. Biotech., 12(23): 3653-3661.

Musa, U. Tanko and U.T. Hassan. 2016. Leaf area determination for maize (Zea mays L.), okra
(Abelmoschus esculeneus L.) and cow pea (Vigna unguiculata L.) crops using linear measurement. J. Biol. Agric. Healthc., 6(4): 104-111.

Nagraj, G., 2009. Oil seeds properties, processing, products and procedures. New Delhi, India: New India Publishing Agency.

Rahman, M.M., M.R. Ali, and M.S. Hossain. 2009. Evaluation of combined management options for managing brinjal shoot and fruit borer. Acad. J. Entomol., 2(2): 92-98.

Rajala, A., P. Peltonen-Sainio, M. Onnela and M. Jackson. 2002. Effects of applying stemshortening plant growth regulators to leaves on root elongation by seedlings of wheat, oat and barley: Mediation by ethylene. Plant Growth Regul., 38: 51-59. https://doi. org/10.1023/A:1020924307455

Sivakumar, R., G. Pathmanaban, M.K. Kalarani, M. Vanangamudi and P.S. Srinivasan. 2002. Effect of foliar application of growth regulators on biochemical attributes and grain yield in pearl millet. Indian J. Plant Physiol., 7(1): 79-82.

Steel, R.G.D., J.H. Torrie and D. Dickey. 1997. Principle and Procedures of Statistics. A biometrical Approach ( $3^{\text {rd }}$ Eds.) McGraw Hill Book Co. Inc. New York, pp. 172-177.

Tripathi, S.C., K.D. Sayre, J.N. Kaul and R.S. Narang. 2003. Growth and morphology of spring wheat (Triticum aestivum L.) culms and their association with lodging: effects of genotypes, $\mathrm{N}$ levels and ethephon. Field Crops Res. J., 84: 271-290. https://doi.org/10.1016/ S0378-4290(03)00095-9

Ullah, M.J., Q.A. Fattah and F. Hossain. 2007. Response of growth, yield attributes and yield to the application of KNAP and NAA in cowpea (Vigna unguiculata L.). Bangladesh J. Bot., 36(2): 127-132. https://doi.org/10.3329/ bjb.v36i2.1500

USDA (United States Department of Agriculture). 2018. World sorghum production 2017-2018.

Viana, D.S., L. Filer and J. Figuerola. 2016. Effect of NAA on grain yield of sorghum. BMC Ecol., 16(1): 3. https://doi.org/10.1186/s12898-016$0057-0$ 